\title{
Types of Career Guidance Work and Prospects for Its Development in a Non-linguistic University
}

\author{
Natalia Krupnova ${ }^{1}$, ${ }^{*}$ Elena Baronova ${ }^{1}$, Karine Vlasova ${ }^{1}$, Olga Volgina ${ }^{1}$ \\ ${ }^{1}$ Lobachevsky State University of Nizhny Novgorod, Russia \\ "Email: krupnova.n.a@yandex.ru
}

\begin{abstract}
This article is devoted to the peculiarities of career guidance work carried out by a pedagogical university. The article defines the concept of career guidance work and summarises the experience of its implementation at the Faculty of History and Philology of the Arzamas branch of the NNSU. The authors describe the system of career guidance work developed and tested by them at the university, consider the most optimal forms and methods of its implementation, identify the types of career guidance activities following their goals, objectives and content. The proposed model makes it possible to attract students to the university, improve the quality of pre-university training, and form a stable motivation for professional activity among future students. The article concludes with the effectiveness of this model, which is determined by its systematic, complex nature, a variety of methods, the introduction of new forms and the use of modern digital technologies.
\end{abstract}

Keywords: Career guidance work, Pedagogical university, Motivation, School Olympiads, Career guidance events, Competitions.

\section{INTRODUCTION}

Career guidance work at the university occupies a significant place and is conducted mainly to attract applicants. It is an essential part of educational work in any higher educational institution, including nonlinguistic. The productive activity of the university depends on the efficiency and literacy of its organisation. Therefore, the management of the educational institution pays special attention to this type of work. The specialisation of our university is the training of secondary school teachers in the Nizhny Novgorod region of our country. Future teachers receive education in different profiles: Russian language and literature, history and social studies, foreign language, biology and geography, etc. Attracting applicants to the walls of our university is an annual task of the management. For its successful solution, a balanced system of career guidance has been developed, taking into account both the interests of specific employers and the peculiarities and needs of the labour market, as well as several other factors. Within the framework of this article, we would like to propose a possible option for organising career guidance work in a non-linguistic university, show and analyse the most exciting forms of its implementation, and reveal potential prospects for the development of this type of work in the future.

\section{THEORETICAL BASIS AND RESEARCH METHODS}

Many researchers have addressed the topic of vocational guidance for schoolchildren. First of all, we can name the works of T.Yu. Tsybizova, N.N. Zaguzina, Bezusova T.A., Shestakova L.G. and others. T.Yu. Tsibizova, for example, draws attention to the formation of professional competence of schoolchildren in the field of information and telecommunication technologies and presents the results of her research on the career guidance of students in this field [1]. Bezusova T.A. and Shestakova L.G. describe active and passive types of career guidance work, give examples of options for their implementation and give recommendations on the organisation of certain types of work [2]. N.N. Zaguzina considers the problems of professional self-determination of students in the 
modern labour market. It reveals the motives for choosing a speciality and factors of professional selfdetermination of students [3]. Klyusova V.V. and Yarkova G.A., considering the possibilities of a pedagogical university in the organisation of vocational guidance for schoolchildren, one of the available forms of this type of work is a distance Olympic [4]. B. Fitzenberger identifies the main factors determining the effectiveness of vocational guidance for schoolchildren [5]. However, all these studies describe career guidance methods at school and aim to work with students to further self-determination in the world of professions. The primary attention is paid to the pre-university preparation of students in the primary subjects of the school course (mathematics, Russian language, history, etc.). We are primarily interested in career guidance activities at the university and the principles of its directed impact on attracting future potential applicants to the walls of the educational institution. Paskar V.S. gives, in our opinion, the complete definition of this concept: "The career guidance activity of an educational institution is considered as a scientifically based system for preparing potential applicants for a free and independent choice of profession, designed to take into account both individual personality characteristics and the need for a full-fledged distribution of labour resources in the interests of society" [6]. Further, the author characterises career guidance work as "a whole range of measures aimed at helping young people enter adulthood (graduates of secondary schools, gymnasiums and secondary vocational institutions) in selfdetermination and choice of professional activities, as well as in their further personal and professional growth." Thanks to purposeful career guidance, students develop competencies that allow them to adapt to the labour market. [Ibid] Similarly, this type of activity is interpreted, and its goals are seen by Bezusova T.A. and Shestakova L.G., placing at the centre of their research "two fundamental directions of the university's career guidance work from the standpoint of methodology: career guidance work to attract applicants to the university and career guidance work for professional self-determination of students" [7].

As well known, there are different classifications of types of career guidance work. E. Kuzmina, in her article, talks about traditional and non-traditional ways of influencing the professional orientation of students [8]. S.V. Titova divides the methods of career guidance into passive and active. She refers to passive methods such as "design of information stands about the directions and profiles of the university; visits by prospective applicants to educational institutions; organisation of an "Open Day"; presentation of university scientists in the media" and others.

These methods, in her opinion, are less efficient and energy-consuming, unlike active forms, which require "more thorough preparation and are aimed at indirectly involving prospective applicants in the world of science and students" [9]. The author names "organising Olympics for schoolchildren, conducting professional weeks of faculties" and others as active career guidance methods. In our opinion, the forms of this type of work should be complex and diverse, including both active and passive methods.

\section{CAREER GUIDANCE WORK AT THE FACULTY OF HISTORY AND PHILOLOGY OF THE ARZAMAS BRANCH OF THE NNSU}

The approximate plan of career guidance activities of our university's Faculty of History and Philology consists of activities of a diverse nature. The work is designed for the whole academic year, is continuous, and is timed either to the most important significant dates of the year or the days of school holidays. Our institution is timed with a specially invented action "Holidays in an adult way" for the holidays. As part of this campaign, a series of events are being held to attract as many students as possible to our university. Masterclasses, interactive lessons, entertaining quizzes and much more are arranged for them. In general, the entire cycle of career-oriented activities can be divided into the following groups:

1. Activities aimed at popularising a particular profile of the faculty;

2. Activities aimed at preparing potential applicants for future studies at the university;

3. Competitive events for schoolchildren;

4. Events for participation in which additional points are given upon admission to the university. We will consider each of these groups in more detail.

\subsection{Activities aimed at popularising a particular profile of the faculty}

This group includes activities such as:

1. Dictionary and Encyclopedia Day;

2. Thanksgiving Day;

3. Phonetic competition "Shakespeare readings", "Reading Goethe, Schiller, Heine";

4. Philologist's Day;

5. German language event "German Fairy Tales";

6. Meetings with teachers and students of schools and others. As part of the events of this block, schoolchildren are usually invited as spectators or direct participants. Most often, these events are prepared by students of our faculty. For example, Thanksgiving is an event that has a long tradition within the walls of our faculty. It allows students of both linguistic and non- 
linguistic profiles to express themselves and students of vocational schools. In the phonetic competition "Shakespeare Readings", poems, excerpts from prose are read, songs are sung, or fragments of dramatic works are played. In addition to pronouncing skills, the jury evaluates the participants' artistry, costume choice, and ability to interact in a group. The German-language event "German Fairy Tales" is aimed at promoting and popularising the German language. The topics of this event can be different: "Travel to German-speaking countries", "Significant dates in German culture", "German-language TV series", "Eurovision with a German accent" and others. Part of the holiday is also aimed at schoolchildren as direct participants. Most often, these are quizzes, contests with their participation.

\subsection{Activities aimed at preparing future potential applicants to study at our university}

These include:

1. Philological studies

2. Interactive workshop "With grammar on "you"

3. Courses on preparation for Total dictation

4. Dictation "We write A.P.Chekhov",
"A.Ostrovsky"

\section{Dictation in English "Train English spelling" \\ 6. Public lectures}

This group's events are attended free of charge by those who wish and are often held during school holidays. "Philological studies" include a cycle of classes in the Russian language for everyone who wants to improve their knowledge in this field. The most challenging topics in the school curriculum and topics beyond the school curriculum are submitted for detailed consideration. Teachers of the Department of Russian Language and Literature explain them in an accessible form, using electronic resources and multimedia visualisation. A considerable number of people of different ages come to the courses to prepare for Total dictation. The control stage of these classes is the dictation "We write A.P.Chekhov", "A.Ostrovsky" and the Total dictation itself, which is organised within the walls of our university. Interactive workshop "With grammar on "you" allows you to gain new knowledge on the grammar of a foreign language. Most often, such classes are informative, exciting and playful, with many quizzes, lotteries and contests of an educational nature. The end of this cycle of events is the dictation in English "Train English spelling". It is read and checked personally by teachers of the Department of Foreign Languages and Cultures. Professors of our faculty conduct public lectures on history, literature and the Russian language. Here are some of them: "Patriarch
Sergius: the feat of serving the church and the motherland" (Titkov E.P.), "The Word about Yesenin" (Pyatkin S.N.), "Ode to Provincial Literature" (Kondratiev B.S.) and others.

\subsection{Competitive events}

The third block includes such events as:

1. Book Trailer

2. Project Fair

3. Competition of scientific works of schoolchildren named after V.I. Vernadsky

4. Linguistic and Cultural Olympic in foreign languages

5. Essay contest "Reflections on the line of I.A. Krylova"

The activities of this plan are aimed at developing the scientific potential of future applicants. As part of this block, they prepare scientific articles, reports and learn to think analytically. Creativity and creative thinking are only welcome at this stage. The most interesting in this group is the Book Trailer Contest. At this event, students and schoolchildren send either presentations or voiced videos that reflect their view of a classic or modern work of fiction. The goal of each speaker is to motivate their classmates to read a book, to get to know the author of prose or poetry in more detail. The creative approach to the topic is evaluated, the ability to present information vividly, interestingly, without forgetting about the phonetic and intonational side of a foreign-language utterance.

Public speaking skills are also crucial for the project fair. Students defend projects in their groups on the topics prescribed by the discipline's work program each semester. They have socially and individually significant issues since the system of values, the idea of the world is decisive in choosing a career, which is emphasised by J. Athanasou when describing "career counselling" [10]. Such topics include "The most significant event in the XXI century", "The history of my family", "Fashion and its significance for young people". Students can use the electronic and paper presentation format in a poster created in pairs or individually. At the end of the year, the best projects are selected. They are defended in the presence of schoolchildren and a jury of teachers.

All the contests mentioned above help show talents, assess the level of competence formation, identify hidden potential, and give a model for one of the essential types of independent work in future professional activity [11]. They develop critical thinking and emotional intelligence, the ability to evaluate sources in terms of their validity and relevance to the topic of the project. Such forms of work allow you to 
get feedback from a wide range of listeners, including those who may be their students in teaching practice tomorrow. M. Coetzee emphasises the importance of this aspect of a professional orientation: "... continuous feedback and evaluation loop that connects Outputs and Inputs phases" (continuous feedback and cyclical evaluation that connects immediate results and introductory information) [12].

\subsection{Events that give additional competitive points}

The fourth block consists of such events:

1. English Language Olympic "English is my Future"

2. Interregional History Olympic "Future Researchers - the Future of Science"

3. Regional competition for schoolchildren "Nizhny Novgorod Volga region in the historical fate of Russia"

The first competition, "Olympic in English "English is my Future", was held in person before Covid-19. Last year it was successfully implemented in the online version. This event is vital in educational terms, as it includes tasks of the Unified State Exam format in a foreign language. At the first stage, students must complete written tasks, understand the text of a journalistic nature, and know the language's grammar and vocabulary. Those who were in the top twenty of the online Olympics enter the second stage. In the second round, on the Zoom platform, participants are invited to complete one of the tasks of the oral part of the Unified State Exam.

The logical continuation of the Olympics was the April trial exam for high school students of the Nizhny Novgorod region. An interactive presentation on the oral part of the Unified State Exam was created. The participants had to enter the "rooms" of the Zoom platform at a particular time, where the department's teacher listened to their answers, commented in detail on the mistakes, strengths and weaknesses of the monologue, and read a fragment of text. As a result, methodological recommendations on preparation for the final testing were sent to the schools that sent students to this event.

The regional contest "Nizhny Novgorod Volga Region in the historical fate of Russia" is dedicated to "the contribution of Nizhny Novgorod residents to the formation of Russian statehood, the development of the economy and culture of the country." This is a longterm project in which schoolchildren from grades 1 to 11 take part. The competition presents four nominations: "Research work", "Family album, family traditions, dynasties", "Poems and prose about the native land", "Articles, essays and essays about writers from Nizhny Novgorod". The following topics are offered for the RW nomination: "Nizhny Novgorod Region in the History of Russia", "Historical portraits of outstanding Nizhny Novgorod residents", "Nizhny Novgorod is the economic and cultural centre of Russia". Schoolchildren from grades 7 to 11 are invited to participate in the interregional History Olympic "Future Researchers - the Future of Science" [13]. In our university, it is organised and conducted by the Department of History and Social Studies.

\section{CONCLUSION}

Thus, career guidance work is a multidimensional labour-intensive process aimed primarily at attracting future applicants to the university, improving the quality of their pre-university training, forming additional motivations and competencies in demand in the labour market. It contributes to developing students' new activity experience, social roles, communication, professional behaviour, qualities. Career guidance work also allows students to significantly expand their knowledge of subjects of interest, go beyond the school curriculum, make an informed choice in favour of a particular professional field and gain personal experience in research and creative activities. The effectiveness of this type of work increases if it is carried out systematically and comprehensively, with a wide variety of forms. Its fruitfulness also depends on the positive image of the educational organisation, which should be formed among school graduates. Its formation is facilitated by using new management methods, the latest information technologies, methodological support and modern material and technical equipment of the educational process. Purposefulness, optimality of forms and methods, timeliness and introduction of new forms - this is where we see further prospects for developing career guidance activities at the university. James Athanasou spoke best about this aspect, pointing out the need in the XXI century "...fit work into life, rather than fit life into work" (to fit work into life, and not turn life into work) [14].

\section{REFERENCES}

[1] T.Y. Tsibizova, Additional education as a form of continuity in the system of continuing education [Dopolnitel'noe obrazovanie kak forma preemstvennosti $\mathrm{v}$ sisteme nepreryvnogo obrazovaniya], Education and self-development [Obrazovanie i samorazvitie] 5(27) (2011) 55-60.

[2] T.A. Bezusova, L.G. Shestakova, Methods of career guidance work of a higher educational institution [Metody proforientacionnoj raboty vysshego uchebnogo zavedeniya], Novalnfo.Ru 54(2) (2016) 216. Retrieved from: 
https://novainfo.ru/archive/?number $=54 \&$ volume= $\underline{2}$

[3] N.N. Zaguzina, The choice of a future profession by high school students as an element of decisionmaking [Vybor starsheklassnikami budushchej professii kak element prinyatiya resheniya], Man and Education [Chelovek i obrazovanie] 4 (2010) 145-147. Retrieved from: http://obrazovanie21.narod.ru/Files/2010-4_p145147.pdf

[4] V.V. Klyusova, G.A. Yarkova, The possibilities of a pedagogical university in the organisation of vocational guidance for schoolchildren [Vozmozhnosti pedagogicheskogo vuza v organizacii proforientacii shkol'nikov], Modern problems of science and education [Sovremennye problemy nauki i obrazovaniya] 2 (2013) 415-423. Retrieved from: https://scienceeducation.ru/ru/article/view?id=8989

[5] B. Fitzenberger, A. Hillerich-Sigg, M. Sprietsma, Different counsellors, many options: Career guidance and career plans in secondary schools, German Economic Review 21(1) (2020) 65-106. Retrieved from: https://doi.org/10.1515/ger-2019$\underline{0027}$

[6] V.S. Paskar, Modern forms of career guidance work in universities [Sovremennye formy proforientacionnoj raboty v VUZah], Scientific and methodological electronic journal "Concept" [Nauchno-metodicheskij elektronnyj zhurnal «Koncept»] 27 (2017) 64-68. Retrieved from: http://e-koncept.ru/2017/574011.htm

[7] T.A. Bezusova, L.G. Shestakova, Methods of career guidance work of a higher educational institution [Metody proforientacionnoj raboty vysshego uchebnogo zavedeniya], Novalnfo.Ru, 54(2) (2016) 219. Retrieved from: https://novainfo.ru/archive/?number $=54 \&$ volume $=$ $\underline{2}$

[8] E. Kuzmina, Career guidance: efficiency and quality [Proforientaciya: effektivnost' i kachestvo], Higher Education in Russia [Vysshee obrazovanie v Rossii] 3 (2002) 24-32.

[9] S.V. Titova, Effective method of vocational guidance activity of the university [Effektivnyj metod proforientacionnoj deyatel'nosti vuza], The World of Modern Science [Mir sovremennoj nauki] 6 (2011) 3-18.

[10] J. Athanasou, International Book of Career Guidance, Sydney, 2020, p. 401.
[11] N. Orellana, Extending the Scope: Career Guidance in Higher Education. Retrieved from: http://www.guninetwork.org/articles/extendingscope-career-guidance-higher-education

[12] M. Coetzee, Career counselling: A manual for career practitioners, Cape Town, 2007.

[13] Future researchers - the future of science [Budushchie issledovateli - budushchee nauki]. Retrieved from: http://www.unn.ru/bibn /

[14] J. Athanasou, International Book of Career Guidance, Sydney, 2020, p. 40. 